\title{
The Influence of Contextual Approach on the Mathematical Understanding and Communication Abilities as seen from Students' Initial Mathematical Abilities
}

\author{
Siti Maryam Sari ${ }^{1 *}$, Hepsi Nindiasari ${ }^{2}$, Cecep Anwar Hadi Firdos Santosa ${ }^{3}$ \\ ${ }_{1,2,3}$ Universitas Sultan Ageng Tirtayasa \\ *maryam.sari07@gmail.com
}

Received: July 2020; Accepted: December 2020; Published: January 2021

\begin{abstract}
The purpose of this research was to determine the effect of a contextual approach on students' mathematical understanding and communication abilities in terms of their initial mathematical ability (KAM) in the Pythagorean Theorem class VIII material. This research was conducted at MTs Al Ihsan Serang City in the academic year 2019-2020 even semester. Methods The research method used is a quasi-experimental, data collection techniques, namely the ability to test mathematical understanding and communication, hypothesis testing using a two-way Manova with a significance level of 5\%. Before testing the hypothesis, the analysis prerequisite test was carried out, namely the multivariate normality and homogeneity test, the test results were the data were normally distributed and homogeneous. From the results of the analysis test using Manova, it can be concluded that: there are differences in the mathematical understanding and communication abilities of students who get a contextual approach with students who get a scientific approach, there are differences in the mathematical understanding and communication abilities of students who get a contextual approach with students who get a scientific approach between high KAM and low, and there is no interaction between learning approaches and KAM on students' mathematical understanding and communication skills.
\end{abstract}

Keywords: contextual approach, understanding, mathematical communication, KAM.

How to cite: Sari, S. M., Nindiasari, H., \& Santosa, C. A. H. F. (2021). The Influence of Contextual Approach on the Mathematical Understanding and Communication Abilities as seen from Students' Initial Mathematical Abilities. Journal of Medives: Journal of Mathematics Education IKIP Veteran Semarang, 5(1), 151-158. 


\section{PENDAHULUAN}

Mutu pendidikan suatu negara dapat dilihat dari ketercapaian pengetahuan dan keterampilan siswanya. Identifikasi ketercapaian pengetahuan dan keterampilan siswa sekolah menengah dapat dilihat dari empat kategori menurut Ontorio Ministry of Educations (2005), yaitu (1) pengetahuan dan keterampilan, (2) berpikir, (3) mengkomunikasikan, (4) mengaplikasikan. Hal ini sejalan dengan tujuan pembelajaran matematika yang ditetapkan kurikulum 2013 yaitu agar siswa mampu memahami konsep matematika, penalaran dan mengkomunikasikan gagasan.

Tujuan yang pertama dalam pembelajaran matematika adalah memahami konsep matematika. Kemampuan pemahaman matematis merupakan dasar dari beberapa kemampuan matematika yang lainnya yang lebih tinggi, seperti kemampuan berpikir kritis dan kemampuan komunikasi matematis, hal ini sejalan dengan yang dikemukakan oleh Arends et al. (2007) mengungkapkan pemahaman konsep adalah dasar untuk bernalar dan berkomunikasi.

Selain kemampuan pemahaman matematis, kemampuan selanjutnya dapat dikembangkan pada mata pelajaran matematika adalah kemampuan komunikasi matematis. Menurut National Council of Teachers of Mathematics atau NCTM, komunikasi matematis adalah kemampuan siswa untuk menyatakan ide-ide matematika baik secara lisan maupun tertulis, dan merupakan kemampuan siswa untuk menyampaikan pesan yang diketahuinya, baik pesan berupa konsep, rumus, maupun strategi penyelesaian suatu masalah matematika.

Sifat matematika yang abstrak menyebabkan banyak siswa mengalami berbagai kesulitan dalam mempelajari matematika terutama dalam memahami dan menyelesaikan masalah matematik. Akibatnya, siswa kurang menghayati atau memahami konsep-konsep matematika dan mengalami kesulitan untuk mengaplikasikan matematika dalam kehidupan sehari-hari. Hal ini berakibat pada pemahaman matematika yang masih rendah. Oleh karena itu diperlukan beberapa upaya salah satunya adalah perbaikan dari segi pembelajaran matematika untuk meningkatkan pemahaman dan komunikasi matematika siswa di sekolah. Selama ini siswa di sekolah menggunakan pendekatan saintifik, namum masih banyak siswa yang belum paham, terlihat dari pencapaian nilai yang masih rendah di bawah KKM.

Salah satu pendekatan pembelajaran yang dapat berpeluang untuk meningkatkan kemampuan pemahaman dan kemampuan komunikasi matematis siswa adalah pendekatan kontekstual, hal ini sejalan dengan penelitian yang telah dilakukan oleh Fuadi et al. (2016) peningkatan kemampuan pemahaman dan penalaran matematis siswa yang mendapat pembelajaran dengan menggunakan pendekatan kontekstual lebih baik daripada siswa yang memperoleh pembelajaran dengan konvensional. Sarassanti et al. (2018), menyatakan peningkatan kemampuan komunikasi matematis dengan menggunakan pembelajaran kontekstual lebih baik daripada siswa yang mendapat pembelajaran konvensional. 
Pada pendekatan kontekstual memiliki sintak pembelajaran yang diawali dengan konstruktivisme yang didefinisikan sebagai pembelajaran generatif, artinya siswa membangun pemahaman sendiri dan pengalaman baru berdasarkan pengetahuan yang dimilikinya. Oleh karena itu Kemampuan Awal Matematis (KAM) penting diperhatikan dalam penerapan pendekatan kontekstual. Kausar (2018) menyatakan bahwa untuk mempelajari ide-ide baru dalam proses pembelajaran matematika berkaitan erat dengan kemampuan awal matematis sebelumnya dan struktur kognitif yang sudah ada.

Berdasarkan uraian di atas dengan adanya pendekatan kontekstual diharapkan dapat mengoptimalkan kemampuan diri siswa terhadap kemampuan pemahaman dan komunikasi matematis. Dengan demikian berdasarkan latar belakang yang telah diuraikan dan berdasarkan penelitian-penelitian yang sejalan yang telah dilakukan sebelumnya, dari kesemua penelitian tersebut belum ada yang membahas tentang pendekatan kontekstual untuk melihat kemampuan pemahaman dan komunikasi matematis berdasarkan kemampuan awal matematis, untuk itu saya akan mencoba mengkaji dan melakukan penelitian dengan judul "Pengaruh Pendekatan Kontekstual terhadap Kemampuan Pemahaman dan Komunikasi Matematis ditinjau dari Kemampuan Awal Matematis Siswa".

\section{METODE PENELITIAN}

Penelitian ini dilaksanakan di MTs Swasta Al Ihsan Kota Serang. Waktu penelitian dilaksanakan pada semester genap tahun pelajaran 2019/2020. Pembelajaran dilaksanakan 6 kali pertemuan, dengan 2 pertemuan untuk melaksanakan pretest dan post-test 4 pertemuan untuk proses pembelajaran di kelas kontrol dan eksperimen. Penelitian ini menggunakan metode penelitian quasi eksperimen dengan teknik non random sampling. Populasi dalam penelitian ini adalah seluruh siswa di MTs. Sampel pada penelitian ini adalah siswa kelas VIII MTs Swasta Al Ihsan yang berjumlah 40 siswa, terdiri dari kelas $8 \mathrm{~A}$ berjumlah 20 siswa dan kelas 8B 20 siswa. Setelah melakukan wawancara dengan guru matematika di sekolah tersebut antara kedua kelasnya memiliki kemampuan yang tidak jauh berbeda, untuk itu pembagian kelas eksperimen dan kelas kontrolnya menggunakan kelas yang telah ada.

Tabel 1. Desain Penelitian

\begin{tabular}{ccc}
\hline Kelompok & Perlakuan & Test \\
\hline E $_{\text {Kontekstual }}$ & $\mathrm{X}$ & $\mathrm{T}$ \\
$\mathrm{K}_{\text {Saintifik }}$ & & $\mathrm{T}$ \\
\hline
\end{tabular}

Lestari \& Yudhaegara (2017), menyatakan desain metode ekperimen untuk kemampuan pemahaman dan komunikasi matematis berdasarkan The Nonequivalent Pretest-Post-test Control Group Design. Dalam desain ini kelompok eksperimen diberikan model pembelajaran dengan pendekatan kontekstual dan kelompok kontrol diberikan model pembelajaran saintifik. Sebelum perlakuan diberikan pretest terlebih dahulu, Setelah perlakuan, kedua kelompok diberikan post-test dengan diberikan isntrumen tes kemampuan pemahaman dan komunikasi matematis. 
Tabel 2. Desain Pengolahan Data Multivariat $2 \times 2$

\begin{tabular}{ccccc}
\hline \multirow{2}{*}{ KAM } & \multicolumn{2}{c}{ Pendekatan Kontekstual (A1) } & \multicolumn{2}{c}{ Pendekatan Saintifik (A2) } \\
& $\begin{array}{c}\text { Pemahaman } \\
\left(\mathbf{Y}_{\mathbf{1}}\right)\end{array}$ & $\begin{array}{c}\text { Komunikasi } \\
\left(\mathbf{Y}_{\mathbf{2}}\right)\end{array}$ & $\begin{array}{c}\text { Peemahaman } \\
\left(\mathbf{Y}_{\mathbf{1}}\right)\end{array}$ & $\begin{array}{c}\text { Komunikasi } \\
\left(\mathbf{Y}_{2}\right)\end{array}$ \\
\hline KAM tinggi $\left(\mathrm{B}_{1}\right)$ & $\mathrm{Y}_{1} \mathrm{~A}_{1} \mathrm{~B}_{1}$ & $\mathrm{Y}_{2} \mathrm{~A}_{1} \mathrm{~B}_{1}$ & $\mathrm{Y}_{1} \mathrm{~A}_{2} \mathrm{~B}_{1}$ & $\mathrm{Y}_{2} \mathrm{~A}_{2} \mathrm{~B}_{1}$ \\
KAM rendah $\left(\mathrm{B}_{2}\right)$ & $\mathrm{Y}_{1} \mathrm{~A}_{1} \mathrm{~B}_{2}$ & $\mathrm{Y}_{2} \mathrm{~A}_{1} \mathrm{~B}_{2}$ & $\mathrm{Y}_{1} \mathrm{~A}_{2} \mathrm{~B}_{2}$ & $\mathrm{Y}_{2} \mathrm{~A}_{2} \mathrm{~B}_{2}$ \\
\hline
\end{tabular}

Penelitian ini menggunakan rancangan multivariat faktorial $2 \times 2$ atau desain Manova dua jalur dengan empat variabel penelitian, yaitu dua varibel terikat dan dua variabel bebas. Variabel terikat yang digunakan adalah kemampuan pemahaman matematis dan kemampuan komunikasi matematis, sedangkan variabel bebas yang digunakan pendekatan saintifik dan Kemampuan Awal Matematis (KAM). KAM siswa dibagi menjadi KAM tinggi dan KAM rendah.

Data pengelompokan dilakukan berdasarkan hasil tes KAM dilakukan pengambilan $27 \%$ dari urutan teratas (untuk KAM tinggi) dan 27\% dari urutan terendah (untuk KAM rendah) di mana angka ini dianggap cukup reliabel dan kontras menurut Naga (Astriani, 2017: 81).

\section{Hipotesis Penelitian}

1. Terdapat perbedaan kemampuan pemahaman dan komunikasi matematis siswa yang memperoleh pendekatan kontekstual dengan siswa yang memperoleh pendekatan saintifik.

2. Terdapat perbedaan kemampuan pemahaman dan komunikasi matematis siswa yang memperoleh pendekatan kontekstual dengan siswa yang memperoleh pendekatan saintifik antara KAM (tinggi dan rendah).
3. Pada kemampuan awal matematis tinggi kemampuan pemahaman dan komunikasi matematis siswa yang memperoleh pembelajaran dengan pendekatan kontekstual lebih baik daripada siswa yang memperoleh pembelajaran saintifik.

4. Pada kemampuan awal matematis rendah kemampuan pemahaman dan komunikasi matematis siswa yang memperoleh pembelajaran saintifik lebih baik daripada siswa yang memperoleh pembelajaran dengan pendekatan kontekstual.

5. Terdapat interaksi antara pendekatan pembelajaran dan kemampuan awal matematis terhadap komunikasi matematis siswa.

\section{HASIL DAN PEMBAHASAN}

Berdasarkan pada ketentuan bahwa untuk uji Manova dua jalur dilakukan uji prasyarat terlebih dahulu yaitu uji normalitas multivariat dan homogenitas, hasilnya tertuang dalam Tabel 3.

Tabel 3. Uji Normalitas Multivariat

\begin{tabular}{lcccc}
\hline \multicolumn{1}{c}{ Kelas } & N & $\begin{array}{c}\text { Jarak } \\
\text { Mahalanobis }\end{array}$ & Qi & $\begin{array}{c}\text { Sig.(2- } \\
\text { Tailed) }\end{array}$ \\
\hline Eksperimen & 20 & 1 & 0,905 & 0,000 \\
Kontrol & 20 & 1 & 0,919 & 0,000 \\
\hline
\end{tabular}

Dari hasil analisis uji normalitas multivariat berdasarkan pada Tabel 3, nilai koefisien korelasi yang diperoleh 0,905 di kelas eksperimen dan 0.919 di kelas kontrol, angka itu menunjukkan 
koefisien korelasi yang sangat tinggi. Besarnya koefisien korelasi antara -1 sampai dengan +1 , terdapat korelasi yang sangat signifikan. Data berdistribusi normal.

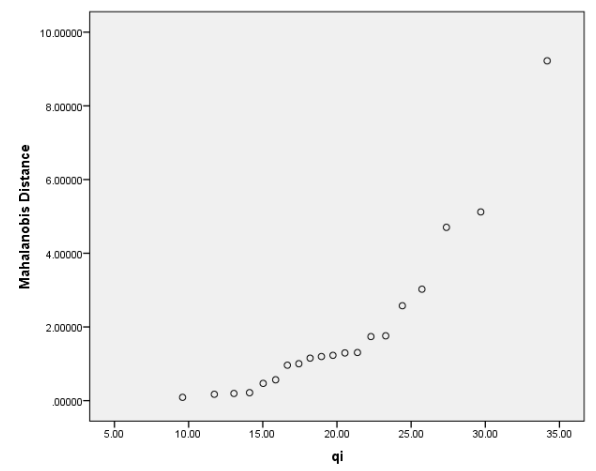

Gambar 1. Scatter-Plot Uji Normalitas Multivariat Kelas Eksperimen

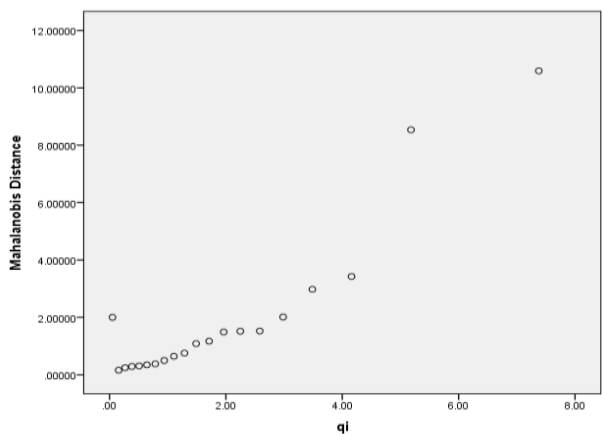

Gambar 2. Scatter-Plot Uji Normalitas Multivariat Kelas Kontrol

Dalam Scatte-plot yang ditunjukkan pada Gambar 1 dan 2 terlihat poinpoinnya mendekati garis lurus yang menunjukkan data berdistribusi normal.

Uji homogenitas data post-test menggunakan uji Box's $M$ test. Dengan kriteria apabila hasil uji Box's M memiliki nilai Sig. $>\alpha=0,05$ maka $\mathrm{H}_{0}$ diterima sehingga data disimpulkan covarian dependen sama atau datanya homogen. Namun jika nilai Sig. $<\alpha=$ 0,05 maka $\mathrm{H}_{0}$ ditolak sehingga data disimpulkan covarian dependen tidak sama atau datanya tidak homogen. Berikut ini hasil analisis Box's M dapat dilihat pada Tabel 4.
Tabel 4. Uji Box's M

\begin{tabular}{ccccc}
\hline $\begin{array}{c}\text { Box's } \\
\text { M }\end{array}$ & F & df1 & Sig. & Simpulan \\
\hline 1,597 & 0,480 & 3 & 0,696 & $\mathrm{H}_{0}$ diterima \\
\hline
\end{tabular}

Kesimpulannya karena nilai Sig. $0,696>\alpha=0,05$ maka $\mathrm{H}_{0}$ diterima sehingga dapat disimpulkan datanya homogen.

Berdasarkan perhitungan uji normalitas menunjukkan bahwa datanya berdistribusi normal. Hasil perhitungan variansi populasi menunjukkan bahwa variansi berasal dari populasi yang homogen.

Oleh karena itu, untuk mengetahui ada atau tidaknya pengaruh dan interaksi antara pendekatan pembelajaran dan kemampuan awal matematis siswa terhadap kemampuan pemahaman dan komunikasi matematis siswa digunakan uji Manova dua jalur. Tabel 5 merupakan tabel pengujian hipotesis pada penelitian dengan signifikansi 0,05 .

Tabel 5. Hasil Analisis Manova

\begin{tabular}{|c|c|c|c|}
\hline $\begin{array}{c}\text { Hipo- } \\
\text { tesis }\end{array}$ & Sig. & Kriteria $\mathbf{H}_{0}$ & Keterangan \\
\hline 1 & 0,003 & $\begin{array}{l}\mathrm{H}_{0<0,05} 05 \\
\mathrm{H}_{0} \text { ditolak }\end{array}$ & Terdapat perbedaan \\
\hline 2. & 0,019 & $\begin{array}{l}\mathrm{H}_{0<} 0,05 \\
\mathrm{H}_{0} \text { ditolak }\end{array}$ & Terdapat Perbedaan \\
\hline 3. & 0,005 & $\begin{array}{l}\mathrm{H}_{0<} 0,05 \\
\mathrm{H}_{0} \text { ditolak }\end{array}$ & Kontekstual lebih baik \\
\hline 4. & 0,421 & $\begin{array}{l}\mathrm{H}_{0>} 0,05 \\
\mathrm{H}_{0} \text { diterima }\end{array}$ & $\begin{array}{l}\text { Saintifik tidak lebih } \\
\text { baik }\end{array}$ \\
\hline 5 & 0,758 & $\begin{array}{l}\mathrm{H}_{0>} 0,05 \\
\mathrm{H}_{0} \text { diterima }\end{array}$ & $\begin{array}{l}\text { Tidak ada interaksi } \\
\text { antara pembelajaran } \\
\text { dan KAM terhadap } \\
\text { kemampuan } \\
\text { pemahaman } \\
\text { komunikasi } \\
\text { matematis. }\end{array}$ \\
\hline
\end{tabular}

Berdasarkan Tabel 5, pada hipotesis pertama, nilai Sig. $0,003<\alpha=0.05$, maka $\mathrm{H}_{0}$ ditolak. Artinya terdapat perbedaan kemampuan pemahaman dan komunikasi matematis siswa yang memperoleh pendekatan kontekstual dengan siswa yang memperoleh pendekatan saintifik, atau dapat dinyatakan 
pendekatan kontekstual lebih baik daripada pendekatan saintifik. Hal ini sejalan dengan yang telah dilakukan oleh Sariningsih (2014) yang mengungkapkan kemampuan pemahaman matematis siswa yang pembelajarannya menggunakan pendekatan kontekstual hasilnya lebih baik daripada pendekatan konvensional. Pendekatan konvensional yang digunakan dalam penelitian ini adalah pendekatan saintifik yang sesuai dengan kurikulum 2013. Hal ini diperkuat oleh analisis jawaban siswa yang mendapatkan pembelajaran dengan pendekatan kontekstual memperoleh hasil yang cukup baik dibanding dengan pendekatan saintifik.

Pada hipotesis kedua nilai Sig. $0,019<\alpha=0.05$, maka $\mathrm{H}_{0}$ ditolak artinya terdapat perbedaan kemampuan pemahaman dan komunikasi matematis siswa yang memperoleh pendekatan kontekstual dengan siswa yang memperoleh pendekatan saintifik antara KAM tinggi dan KAM rendah. Pada siswa KAM tinggi cocok menggunakan pendekatan kontekstual karena siswa yang memiliki KAM tinggi sudah memiliki pengetahuan awal yang baik, sehingga dengan pendekatan kontekstual siswa dapat mengkonstruksi ide-ide dan pengetahuannya yang telah mereka miliki, sebagai dasar dalam memahami materi yang akan dipelajari.

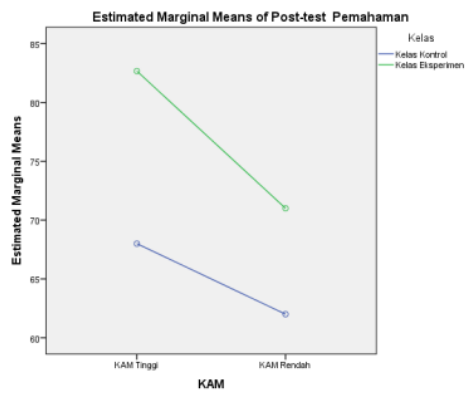

Gambar 3. Interaksi antara Pendekatan Pembelajaran dan KAM terhadap Kemampuan Pemahaman Matematis

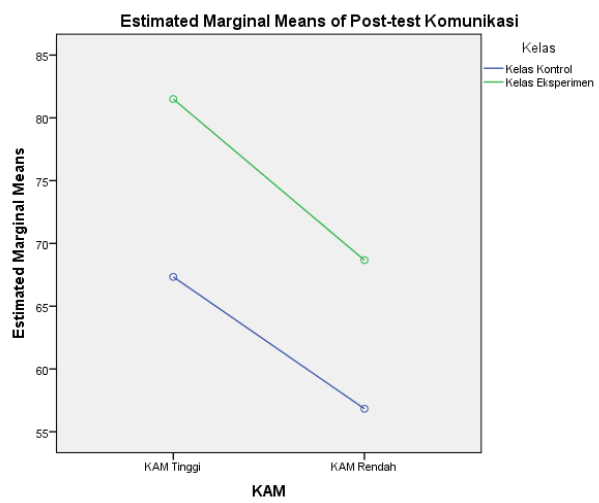

Gambar 4. Interaksi antara Pendekatan Pembelajaran dan KAM terhadap Kemampuan komunikasi Matematis

Sesuai dengan jawaban hipotesis pada nomor dua, dan berdasarkan Gambar 3 dan 4 tidak ada perpotongan antara kedua garis maka tidak adanya interaksi pendekatan pembelajaran dan kemampuan awal matematis terhadap kemampuan pemahaman dan komunikasi matematis siswa. Maka pada hipotesis tiga kesimpulannya $\mathrm{H}_{0}$ ditolak, yang artinya Pada kemampuan awal matematis tinggi kemampuan pemahaman dan komunikasi matematis siswa yang memperoleh pembelajaran dengan pendekatan kontekstual lebih baik daripada siswa yang memperoleh pembelajaran saintifik.

Dengan kata lain pembelajaran kontekstual cocok untuk siswa yang memiliki KAM tinggi. Pada siswa dengan KAM rendah cenderung mengalami kesulitan karena kelompok ini belum memiliki cukup pengetahuan awal matematis, oleh karena itu siswa di kelas eksperimen yang memiliki KAM rendah hasil post-testnya pun nilainya rendah. Akan tetapi masih lebih tinggi dibanding siswa dengan KAM rendah di kelas kontrol.

Pada siswa dengan KAM tinggi di kelas kontrol hasil kemampuan pemahaman dan komunikasi matematisnya 
lebih rendah dibanding pada kelas eksperimen, hal yang sama pada hasil yang diperoleh pada KAM rendah, hasil kemampuan pemahaman dan komunikasi matematis siswa pada KAM rendah di kelas kontrol lebih kecil dari siswa pada KAM rendah di kelas eksperimen.

Berdasarkan hasil dari analisisnya pada penelitian ini tidak terdapat interaksi antara pendekatan pembelajaran dengan KAM terhadap kemampuan pemahaman dan komunikasi matematis. Hal ini menunjukkan bahwa kemampuan pemahaman dan komunikasi matematis hanya dipengaruhi oleh pendekatan pembelajarannya.

\section{PENUTUP}

\section{Simpulan}

Berdasarkan analisis terhadap hasil penelitian dan pembahasan yang telah diuraikan pada bagian sebelumnya, diperoleh kesimpulan sebagai berikut.

(1) Terdapat perbedaan kemampuan pemahaman dan komunikasi matematis siswa yang memperoleh pendekatan kontekstual dengan siswa yang memperoleh pendekatan saintifik.

(2) Terdapat perbedaan kemampuan pemahaman dan komunikasi matematis siswa yang memperoleh pendekatan kontekstual dengan siswa yang memperoleh pendekatan saintifik antara KAM (tinggi dan rendah).

(3) Pada kemampuan awal matematis tinggi kemampuan pemahaman dan komunikasi matematis siswa yang memperoleh pembelajaran dengan pendekatan kontekstual lebih baik daripada siswa yang memperoleh pembelajaran saintifik.
(4) Pada kemampuan awal matematis rendah kemampuan pemahaman dan komunikasi matematis siswa yang memperoleh pembelajaran saintifik tidak lebih baik daripada siswa yang memperoleh pembelajaran dengan pendekata kontekstual.

(5) Tidak terdapat interaksi antara pendekatan pembelajaran dan kemampuan awal matematis terhadap kemampuan pemahaman dan komunikasi matematis siswa.

\section{Saran}

Berdasarkan simpulan di atas maka penulis mengemukakan beberapa saran sebagai berikut.

(1) Pendekatan kontekstual dapat digunakan membantu siswa untuk memperoleh pemahaman dan komunikasi matematis lebih baik dibandingkan dengan menggunakan pembelajaran saintifik

(2) Siswa perlu dibiasakan untuk menggali informasi dari berbagai sumber secara mandiri sehingga terbiasa membangun pengetahuan mereka sendiri.

(3) Pembentukkan kelompok secara heterogen merupakan salah satu upaya guru untuk membantu siswa yang memiliki KAM rendah, Siswa dengan kemampuan awal matematika tinggi dan kemampuan awal matematika rendah disatukan dalam satu kelompok sehingga pada saat terjadi diskusi siswa dengan kemampuan awal matematika tinggi dapat menjelaskan materi yang sedang dipelajari kepada siswa dengan kemampuan awal matematika rendah. 
(4) Diperlukan waktu yang berbedabeda bagi masing-masing siswa untuk mengembangkan kemampuan pemahaman dan komunikaasi matematisnya dalam pembelajaran kontekstual bergatung pada respon masing-masing. Disarankan bagi peneliti selanjutnya untuk mengefisienkan waktu agar pelaksanaan pembelajaran dengan pendekatan kontekstual lebih maksimal.

\section{DAFTAR PUSTAKA}

Arends, Richards I., Kilcher, Ann. (2007). Teaching For Student Learning. New York: Routledge.

Astriani, L. (2017). Pengaruh pembelajaran reciprocal teaching terhadap kemampuan pemahaman konsep matematika ditinjau dari kemampuan awal matematika siswa. FIBONACCI Pendidikan Matematika Dan Matematika, 3(1), 77-85. Retrieved from http:/ /jurnal. um.ac.id/index.php/fbc.

Fuadi, R., Johar, R., \& Munzir, S. (2016). Peningkatkan Kemampuan Pemahaman dan Penalaran Matematis melalui Pendekatan Kontekstual. 3(1), 47-54. https://doi.org/10.24815/jdm.v3i1. 4305 .

Kausar, Aufal. (2018). Peningkatan Kemampuan Komunikasi Matematis Dan Self-Efficacy Siswa Dengan Pendekatan Kontekstual [Tesis]. Bandung [ID] Universitas Pendidikan Indonesia.

Lestari. \& Yudhanegara. (2017). Penelitian Pendidikan Matematika. Bandung: Refika Aditama.
NCTM. (2000). Principle And Standars For School Mathematics. United states . NCTM.

Ontario Ministry Education. (2005). Capacity building series secretariat special.

Sarassanti, Y., Prawanto, S., \& Cahya, E. (2018). Penerapan pembelajaran kontekstual untuk meningkatkan kemampuan komunikasi matematis dan sikap siswa smp. Jurnal Penelitian Pendidikan, 17(3), 199-204

Sariningsih, R. (2014). Pendekatan kontekstual untuk meningkatkan kemampuan pemahaman matematis siswa SMP. Infinity Journal, $3(2), \quad 150$. https://doi.org/10.22460/infinity.v $3 \mathrm{i} 2.60$. 